\title{
Pengaruh Sistem Informasi Inventory Pergudangan terhadap Kinerja Karyawan Bagian Operasional di PT. YCH Indonesia
}

\author{
Wardoyo Wicaksono ${ }^{1}$, Cundo Harimurti ${ }^{2}$ \\ ${ }^{1,2}$ Institut Ilmu Sosial dan Manajemen STIAMI, Jakarta, Indonesia \\ ${ }^{1}$ wardoyo.wicaksono@gmail.com, ${ }^{2}$ cundoharimurti@gmail.com \\ * Wardoyo Wicaksono
}

\section{ARTICLE INFO}

Article history

Received 2020-10-18

Revised 2020-10-25

Accepted 2020-10-31

Keywords

Inventory Information System, Employee Performance, Simple Linier Regression

\begin{abstract}
This study is carried out at PT.YCH Indonesia. The objective of this study is to analyze significance of influence of warehouse information system to performance of operational department's employee at PT. YCH Indonesia. This study used quantitative research method by giving questionnaires to 71 respondents, computation and data analysis used SPSS progam version 16. From the data processing found a correlation value of 0.724 , thereby it can be concluded that a correlation between inventory information system variable $(X)$ toward employee performance $(Y)$ has strong correlation. Result of $R$ square (R2) value of 0.569 or in the amount of $56.9 \%$, therefore it can be said that inventory information system variable has the influence in the amount of $56.9 \%$ and the remaining of $43.1 \%$ is another influence not subject to research. Result of test identified that $t$ count is in the amount of 9.543, therefore $\mathrm{HO}$ is rejected and $\mathrm{HI}$ is accepted because tcount 9.543 > ttable 1.667 and can be said that inventory information system has significant influence to customer's satisfaction. Result of test identified that tcount 4.592 thereby $\mathrm{HO}$ is rejected and Ha accepted because tcount 4.592 $>$ ttable 1.673 and significance $0.000<0.1$, and can be said that warehouse inventory information system has significant influence to employee performance.
\end{abstract}

\section{A. PENDAHULUAN}

Dinamika pertumbuhan ekonomi global saat ini menuntut pelaku ekonomi yang bergerak di bidang apapun untuk dapat meningatkan kemampuannya dalam menghadapi ketatnya persaingan, baik persaingan dibidang layanan penyedia jasa pergudangan dan jasa transportasi dalam ketepatan waktu pendistribusian produk sampai ke tangan konsumen. Kebutuhan terhadap jasa logistik di seluruh dunia berangsur- angsur mengalami peningkatan yang signifikan. Hal ini secara langsung menyebabkan model bisnis yang ada semakin berkembang. Perusahaan logistik berlomba-lomba menyediakan sebuah inovasi demi mempertahankan pangsa pasar mereka. Dalam dunia persaingan logistik sebuah inovasi dalam menciptakan nilai tambah dan melayani pelanggan dengan baik dibutuhkan. Kondisi ini dikarenakan perusahaan pelanggan berlomba- lomba melaksanakan strategi dengan membuat seluruh proses bisnis berjalan efisien, lebih fokus terhadap kompetensi inti mereka, dan memanfaatkan kegiatan outsourcing dalam menjalankan fungsifungsi yang dianggap dapat ditangani dengan baik oleh pihak selain perusahaan (Zacharia, 2011). Salah satu model logistik yang saat ini banyak dimanfaatkan oleh beberapa perusahaan adalah third-party logistics (3PL).

YCH Indonesia telah berkontribusi pada pengembangan rantai pasokan ekonomi terbesar di Asia Tenggara sejak 2003. Terlepas dari medan geografis negara yang kompleks, YCH Indonesia telah menciptakan perbedaan yang kuat dalam operasi rantai pasokannya yang mampu mengelola lebih dari 10 juta karton throughput sebulan, dari pusat distribusi tunggal. YCH memiliki lebih dari 20 fasilitas di seluruh Indonesia, dengan hub utama kami di Cibitung, Jakarta dan Semarang, menawarkan fitur ambien, beku dan pendingin yang mendukung distribusi nasional untuk sektor FMCG yang berkembang pesat. 
Untuk proses operasional gudang, YCH Indonesia menerapkan system informasi inventory gudang milik sendiri yaitu Y3 untuk mendukung distribusi nasional dan keterlacakan produk. YCH Indonesia menganalisis saluran distribusi lokal dan perilaku pesanan. Membangun berdasarkan pengalaman di Asia dan fokus pada pencapaian kecepatan dalam rute ke pasar, cross dock dan titik-titik suplai didirikan untuk mendukung replenishment stok tepat waktu untuk saluran tradisional maupun modern. Ini melengkapi proses baru untuk memantau tingkat stok secara akurat dan memicu replenishment otomatis, yang dikembangkan dalam kolaborasi dengan mitra di sepanjang rantai pasokan. Keakraban dengan lingkungan setempat memungkinkan YCH Indonesia untuk merespons dengan cepat peraturan pemerintah dan pengembangan infrastruktur.

Sejatinya system informasi inventory pergudangan digunakan untuk mempermudah proses operasional gudang, tetapi pada pelaksanaannya tidak selalu berjalan dengan sebagaimana mestinya, terkadang sistem justru menjadi penghambat kinerja karyawan bagian operasional. Contohnya : 1) pada saat proses loading produk kedalam truk, jika ditemukan ada produk yang mengalami kegagalan kualitas atau damage maka produk tersebut harus diganti dengan produk yang memenuhi standar kualitas dan proses penggantian tersebut memakan waktu dikarenakan adanya proses penghapusan BPL (Batch Picking List) pada order tersebut kemudian BPL (Batch Picking List) diinput kembali pada system dengan menyertakan produk baru yang memenuhi standar kualitas. 2) pada saat proses picking ditemukan oleh picker HU (handling unit) label atau biasa dikenal dengan pallet label yang sobek, rusak atau hilang mengharuskan team operasional untuk melakukan print ulang agar barcode pada HU label dapat discan pada saat proses picking. Dari rata-rata order yang diterima oleh PT.YCH Indonesia setiap bulan yaitu berkisar antara 5000 - 6000 order setiap bulan, 2 permasalahan diatas terjadi dengan persentase rata-rata setiap bulannya $0,25 \%-0,50 \%$.

\section{Identifikasi Masalah}

Selanjutnya berdasarkan uraian diatas penulis menyusun rumusan yang menjadi permasalahan pada penelitian ini yaitu:

a. Apakah terdapat pengaruh antara sistem informasi inventory pergudangan terhadap kinerja karyawan bagian operasional di PT.YCH Indonesia?

b. Berapa besar pengaruh system informasi inventory pergudangan terhadap kinerja karyawan bagian operasional di PT. YCH Indonesia?

\section{Maksud dan Tujuan Penelitian}

Berdasarkan identifikasi masalah diatas maka yang menjadi tujuan dalam penelitian ini adalah :

a. Untuk menganalisis apakah terdapat pengaruh antara sistem informasi inventory pergudangan terhadap kinerja karyawan bagian operasional di PT.YCH Indonesia dan

b. Berapa besar pengaruh system informasi inventory pergudangan terhadap kinerja karyawan bagian operasional di PT. YCH Indonesia.

\section{B. KAJIAN LITERATUR}

\section{Sistem Informasi Inventory}

Menurut A.A.K Oka Sudana (2007) inventori (persediaan) adalah bahan baku, produk setengah jadi, produk jadi yang berada di dalam sistem produksi pada suatu waktu, yang bersifat sebagai buffer (penyangga) yang belum digunakan (idle) yang mempunyai nilai ekonomis di masa mendatang pada saat aktif fungsi dari manajemen inventory:

a. perencanaan inventory: menentukan kebutuhan material untuk memenuhi kebutuhan sesuai rencana operasi dan produksi yang telah disusun, yaitu berapa banyak yang harus dipesan.

b. pengendalian inventory: menentukan tingkat inventory yang sesuai dimana pemesanan harus dilakukan kembali, persediaan pengaman, dan kondisi inventory tersebut yang terkait. 
Sistem perencanaan dan pengendalian inventory yang efektif akan memberikan pemenuhan kebutuhan secara tepat baik waktu, jumlah maupun spesifikasi, dengan total biaya persediaan yang optimal.

Alasan-alasan perlunya inventory:

c. Kebutuhan tidak bisa konstan / sesuai dengan due date yang telah ditentukan.

d. Fuktuasi (naik/turunnya) harga barang yang dipesan.

e. Ketidakpastian kebutuhan bahan terhadap order yang diterima.

f. Harga: harga beli perunit jika item diperoleh dari vendor (supplier luar) atau biaya produksi per unit bila item tersebut diproduksi sendiri.

g. Capital cost: jumlah modal yang terkait pada item yang disimpan, suku bunga i\% dikalikan dengan harga beli / produksi.

h. Carrying cost (holding cost), dapat meliputi:

1) biaya depresiasi

2) biaya asuransi dan pajak

3) biaya pemakaian area / ruang serta fasilitas-fasilitas dalam ruang penyimpanan maupun fasilitas penanganan baik secara fisik maupun yang berkaitan dengan data / informasi inventory.

i. Ordering cost: meliputi biaya-biaya persiapan dan peletakkan order (pesanan) inventory, biaya handling dan pengiriman order, biaya pemeriksaan order yang datang. jika item diproduksi sendiri maka disebut setup cost, yang meliputi biaya persiapan / setup mesin untuk produksi. biaya ini ditentukan untuk setiap kali pesanan / setup/

j. Shortage cost: biaya ini timbul jika inventory tidak tersedia pada saat dibutuhkan. biaya ini meliputi biaya karena kehilangan kesempatan untuk memperoleh keuntungan dari penjualan biaya karena kehilangan/ turunya reputasi perusahaan, ketidakpuasan pelanggan, biaya-biaya administrasi yang terkait dalam usaha untuk mempertahankan permintaan yang tidak dipenuhi langsung.

\section{Sistem Informasi Inventory Gudang}

Sistem informasi inventory gudang merupakan sebuah sistem yang mengatur dan mengelola semua barang yang ada di gudang terdiri dari barang jadi (finish goods). Sistem ini dapat memberikan informasi inventory seperti informasi pengeluaran barang, pembelian barang, penerimaan barang dan informasi lain secara cepat dan akurat.

\section{Alat Ukur Sistem Informasi Inventory Pergudangan}

Nilai dari sistem informasi ditentukan dari dua hal, yaitu manfaat dan biaya mendapatkannya. Suatu informasi dikatakan bernilai bila manfaatnya lebih efektif dibandingkan dengan biaya mendapatkannya (Jogiyanto, H.M, 2010:11). Pengukuran suatu nilai informasi biasanya dihubungkan dengan Analysis Cost Effectiveness atau Cost Benefit. Adapun 12 (dua belas) sifat yang merupakan alat ukur nilai sistem informasi yaitu sebagai berikut:

a) Akurat (accuracy) : bebas dari kesalahan, tidak bias / menyesatkan, jelas mencerminkan maksudnya.

b) Bentuk (form) : kualitatif atau kuantitatif, numerical atau berupa grafik, ringkas atau rinci.

c) Frekuensi (frequency) : seberapa sering informasi dibutuhkan, dikumpulkan atau dihasilkan.

d) Kelebarannya (breadth) : ruang lingkup, meliputi berbagai bidang atau hanya satu bidang saja.

e) Asal (origin) : informasi berasal dari dalam atau dari luar perusahaan / organisasi.

f) Orientasi waktu (time horizon) : informasi dapat berorientasi pada masa lalu, masa kini dan masa yang akan datang.

g) Tepat pada waktunya (timeliness) : informasi yang diperlukan untuk pengambilan keputusan tidak boleh terlambat, keterlambatan dapat mengakibatkan informasi tidak mempunyai nilai lagi.

h) Relevan (relevance) : mempunyai manfaat untuk digunakan sebagaimana mestinya, sesuai peruntukkannya. 


\section{E-ISSN 2621-6442}

i) Lengkap (completeness) : mengandung semua data - data yang penting yang dibutuhkan semua pengguna informasi.

j) Ekonomis (economies) : informasi yang dihasilkan melalui proses yang ekonomis (dari segi biaya)

k) Sederhana (simple) : informasi sebaiknya tidak terlalu kompleks, tidak bertele - tele sehingga memudahkan penentuan prioritas.

1) Dapat dibuktikan (approved) : informasi harus dapat dibuktikan, dapat di cek kebenarannya

\section{Kinerja}

Menurut Faustino Cardoso Gomes (2003 : 142), kinerja adalah Outcome yang dihasilkan dari suatu fungsi pekerjaan dalam suatu periode waktu tertentu atau pada saat ini. Pengertian kinerja menurut A.A. Anwar Prabu Mangkunegara (2000:67), kinerja berasal dari kata job performance atau actual performance (prestasi kerja atau prestasi sesungguhnya yang dicapai oleh seseorang). Kinerja adalah "hasil secara kualitas dan kuantitas yang dicapai oleh seseorang pegawai dalam melaksanakan tugas sesuai dengan tanggung jawab yang diberikan kepadanya".

Sedangkan menurut Veithzal Rivai (2004:309) menyatakan bahwa "kinerja merupakan suatu fungsi dari motivasi dan kemampuan" dan mengemukakan faktor-faktor yang mempengaruhi kinerja karyawan atau pegawai, yaitu : kuantitas input, kualitas output jangka waktu output, kehadiran tempat kerja dan sikap kooperatif. Hal itu juga dinyatakan oleh Ambar Teguh Sulistiyani (2003:223) kinerja seseorang merupakan kombinasi dari kemampuan, usaha dan kesempatan yang dapat dinilai dari hasil kerjanya.

Berdasarkan definisi kinerja yang dikemukakan oleh beberapa ahli diatas, maka dapat disimpulkan bahwa kinerja merupakan kualitas dan kuantitas hasil kerja individu dan kelompok dalam suatu aktifitas atau periode tertentu yang dilibatkan oleh kemampuan dan keinginan berprestasi.

\section{Penilaian Kinerja}

Menurut A.A. Anwar Prabu Mangkunegara (2005:33) standar penilaian kinerja yaitu:

a) Kualitas kerja yang meliputi ketepatan, ketelitian, ketrampilan, serta kebersihan.

b) Kuantitas kerja yang meliputi output rutin, serta output non rutin (ekstra).

c) Motivasi menckup meransang dan membankitkan semangat diri sendiri dan orang lain.

d) Inisiatif yang meliputi gagasan, metode dan pendekatan baru.

Menurut Attwood dan Dimmock dalam Sedarmayanti (2007:263), tujuan peilaian kinerja adalah sebagai berikut :

a) Membantu meningkatkan kinerja.

b) Menetapkan sasaran bagi kinerja perorangan.

c) Menilai kebutuhan pelatihan dan pengembangan.

d) Menyepakati rencana untuk pengembangan pegawai di masa depan.

e) Menlai potensi di masa depan untuk kenaikan pangkat.

f) Memberi umpan balik kepada pegawai mengenai kinerja mereka.

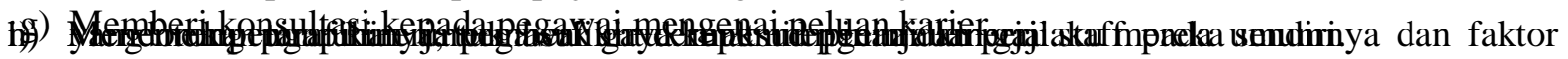

Kontribusi hasil-hasil penilaian merupakan suatu yang sangat bermanfaat bagi perencanaan kebijaksanaan organisasi adapun secarra terperinci penilaian kinerja bagi organisasi adalah :

a) Perbaikan kinerja.

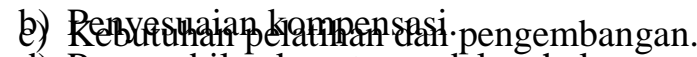

d) Pengambilan keputusan dalam hal penempatan, promosi, mutasi, pemecatan, pemberhentian dan perencanaan tenaga kerja. 
e) Memberi kesempatan kerja yang adil.

f) Membantu diagnosis terhadap kesalahan desain pegawai.

g) Menilai proses rekruitmen dan seleksi.

\section{Kerangka Pemikiran}

Dari berbagai teori yang menjelaskan mengenai Sistem Informasi Inventory pergudangan dan kinerja karyawan bagian operasional dapat peneliti simpulkan dalam sebuah kerangka pemikiran, sebagai gambaran sederhana atas permasalahan yang akan diteliti dalam penelitian ini. Kerangka pemikiran yang ada dalam penelitian ini digambarkan sebagai berikut:

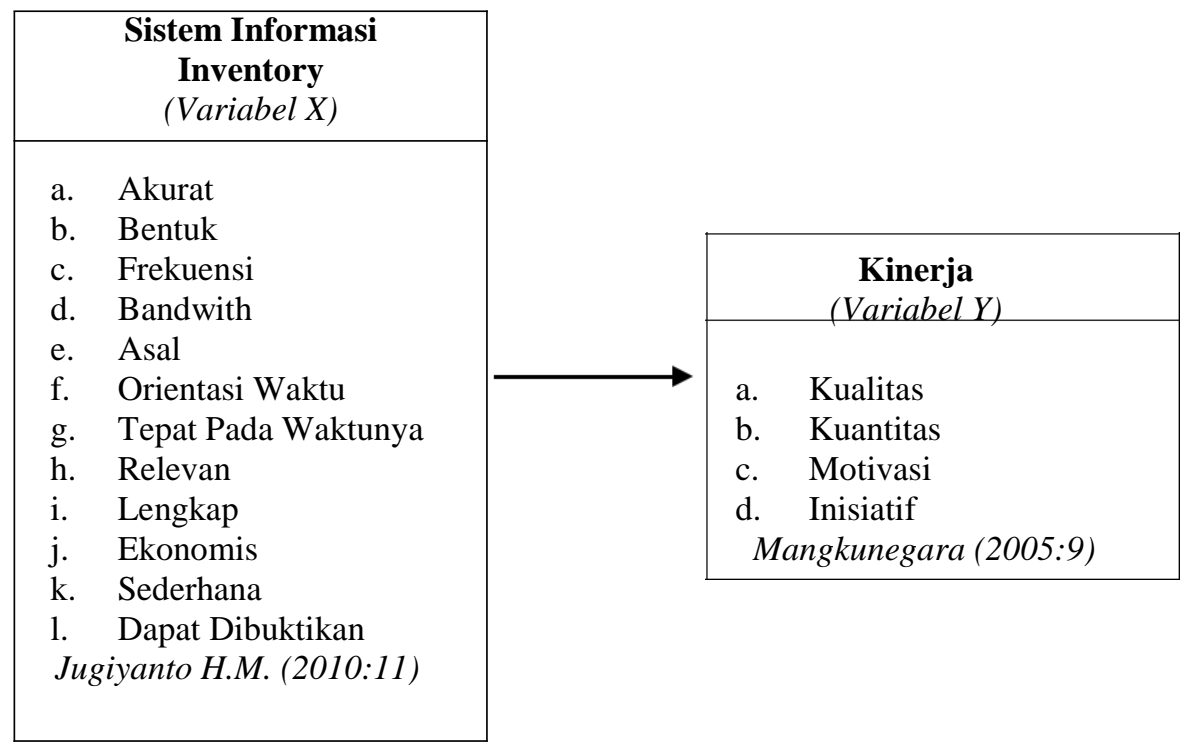

Gambar 1. pengaruh sistem informasi inventory pergudangan terhadap kinerja karyawan bagian operasional

\section{METODE PENELITIAN}

\section{Pendekatan dan Jenis Penelitian}

Dalam penelitian ini penulis menggunakan pendekatan kuantitatif. Pendekatan kuantitatif adalah pengukuran data kuantitatif dan statistik objektif melalui perhitungan ilmiah berasal dari sampel orang-orang atau penduduk yang diminta menjawab atas sejumlah pertanyaan tentang survey untuk menentukan frekuensi dan prosentase tanggapan mereka untuk mengukur pengaruh sistem informasi inventory pergudangan terhadap kinerja karyawan bagian operasional di PT. YCH Indonesia. Dimana dalam penelitian ini akan menguji pengaruh sistem informasi inventory pergudangan terhadap kinerja karyawan bagian operasional di PT. YCH Indonesia, sehingga dengan metode pendekatan kuantitatif penulis mengharapkan akan mendapatkan data, hasilnya diolah, kemudian dianalisis dan disimpulkan. Dan kesimpulan itu berlaku untuk seluruh populasi, sehingga tujuan penelitian dapat dicapai secara efektif.

\section{Operasionalisasi Variabel}

Sesuai dengan judul penelitian yang dipilih penulis yaitu pengaruh sistem informasi inventory pergudangan terhadap kinerja karyawan bagian operasional di PT.YCH Indonesia, maka penulis mengelompokan variabel yang digunakan dalam penelitian ini Sistem Informasi Inventory menjadi variabel independen (X) dan Kinerja Karyawan sebagai variabel dependen (Y). Penelitian ini menggunakan variable dengan indikator seperti berikut : 
Tabel 1. Indikator Variabel

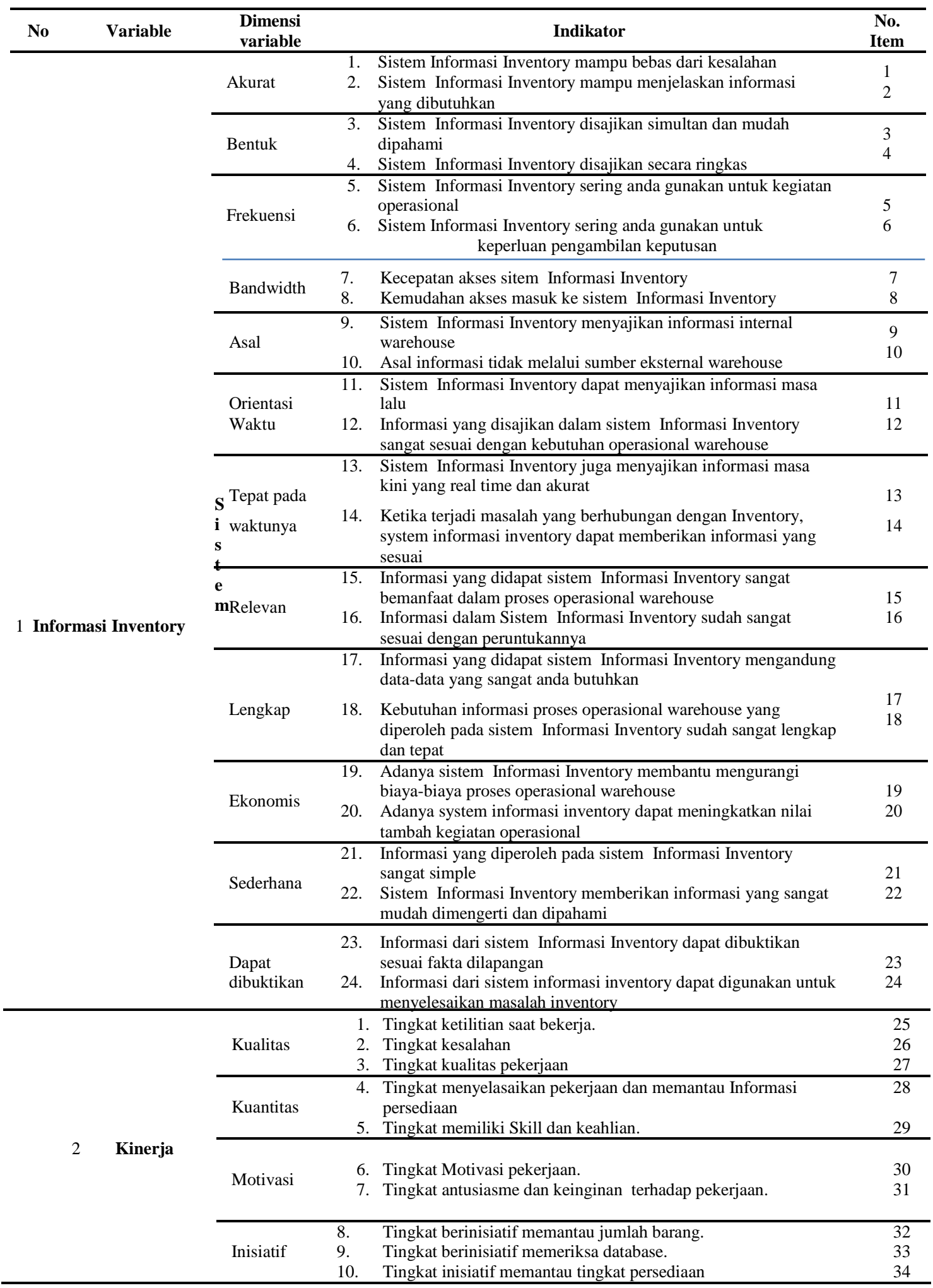




\section{Teknik Pengumpulan Data}

Dalam penelitian ini penulis berusaha untuk memperoleh beberapa informasi dari pengetahuan yang dapat dijadikan pegangan dalam penelitian yaitu dengan cara studi kepustakaan untuk mempelajari, meneliti, mengkaji, dan menelaah literature-literatur berupa buku, jurnal, bulletin, hasil symposium yang berhubungan dengan penelitian untuk memperoleh bahan-bahan yang akan dijadikan landasan teori.

Selain itu penulis juga menggunakan kuesioner yaitu teknik pengumpulan data yang dilakukan dengan cara memberi seperangkat pertanyaan atau pertanyaan tertulis kepada responden untuk dijawab. Jawaban atas pertanyaan diukur dengan menggunakan skala likert yaitu skala yang mempunyai tingkat gradasi dari yang sangat positif sampai dengan sangat negatif, juga menganalisa data secara kuantitatif.

\section{Populasi dan Sampel}

Teknik pengambilan sampel secara random sampling digunakan dengan tujuan untuk memperoleh sampel yang representatif dengan melihat populasi karyawan PT.YCH Indonesia sehingga peneliti mengambil sampel dari seluruh department yang terlibat dalam operasioanal warehouse dan dari masing-masing departemen diambil wakilnya sebagai sampel. Untuk menentukan besarnya sampel yang diambil dari populasi peneliti menggunakan rumus yang dikemukakan oleh slovin dalam Mustafa (2010:90) dengan tingkat kepercayaan 90\% dengan nilai

$$
\begin{aligned}
& \mathrm{e}=10 \% \text { adalah sebagai berikut: }=\overline{1+2} \\
& n=\text { Jumlah sample minimal } \\
& N=\text { Populasi } \\
& e=\text { error margin }(10 \%)
\end{aligned}
$$

Jumlah sample minimal dari penelitian ini adalah :

$$
\begin{aligned}
& =\frac{248}{1+\left(248 \times 0,1^{2}\right)} \\
& =\frac{1+(248 \times 0,01)}{248} \\
& =\frac{1+2,48}{} \\
& =3,48 \\
& =71
\end{aligned}
$$

Maka jumlah sample minimal yang diambil dari populasi adalah sebanyak 71 karyawan dengan detail sebagai berikut : 
Tabel 2. Populasi dan Sampel Penelitian

\begin{tabular}{clcc}
\hline \multirow{2}{*}{ NO } & \multirow{2}{*}{ DEPARTMENT } & JUMLAH & JUMLAH \\
& & KARYAWAN & SAMPEL \\
\hline 1 & Distribution & 22 & 6 \\
\hline 2 & Finance \& Accounting & 4 & 1 \\
\hline 3 & Inbound & 34 & 10 \\
\hline 4 & Information Technology & 6 & 2 \\
\hline 5 & Inventory & 18 & 5 \\
\hline 6 & Outbound & 87 & 25 \\
\hline 7 & Quality Control & 37 & 11 \\
\hline 8 & RMPM & 31 & 9 \\
\hline 9 & Value Add & 9 & 3 \\
& JUMLAH & $\mathbf{2 4 8}$ & $\mathbf{7 1}$
\end{tabular}

\section{Teknik Analisis Data}

a. Uji Validitas

Validitas menunjukkan ukuran yang benar-benar mengukur apa yang akan diukur. Jadi dapat dikatakan semakin tinggi validitas suatu alat test, maka alat test tersebut semakin mengenai pada sasarannya, atau semakin menunjukkan apa yang seharusnya diukur. Salah satu cara untuk menghitung validitas suatu alat test yaitu dengan melihat daya pembeda item (item discriminality). Daya pembeda item adalah metode yang paling tepat digunakan untuk setiap jenis test. Daya pembeda item dalam penalitian ini dilakukan denan cara: "korelasi item-total". yang dalam penelitian ini menggunakan koefisien korelasi Pearson Product Moment dengan langkah-langkah perhitungan sebagai berikut : Koefisien Korelasi Product Moment

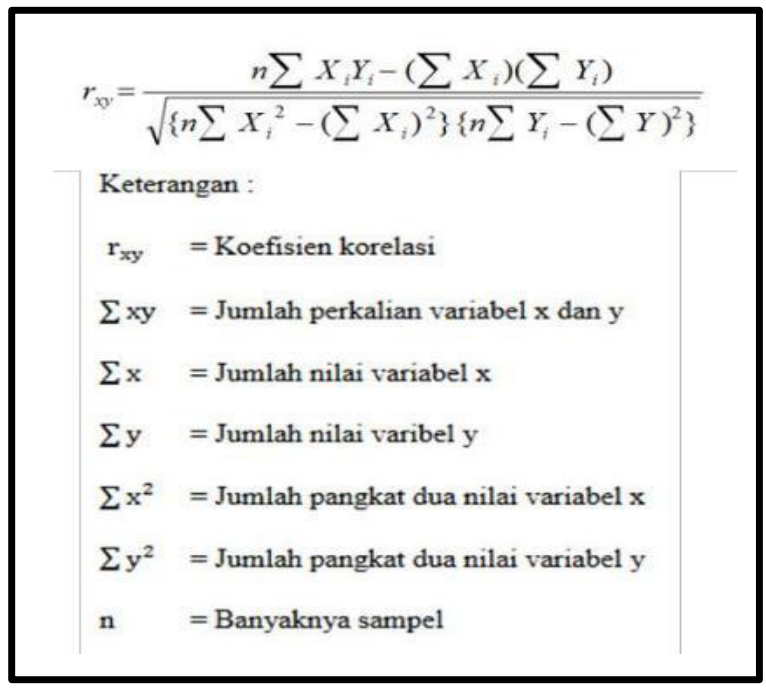

\section{b. Uji Reliabilitas}

Reliabilitas merupakan salah satu ciri atau karakter utama intrumen pengukuran yang baik. Kadang-kadang reliabilitas disebut juga sebagai keterpercayaan, keterandalan, keajegan, konsistensi, kestabilan, dan sebagainya, namun ide pokok dalam konsep reliabilitas adalah sejauh mana hasil suatu pengukuran dapat dipercaya, artinya sejauh mana skor hasil pengukuran terbebas dari kekeliruan pengukuran (measurement error). Tinggi rendahnya reliabilitas, secara empiris ditunjukkan oleh suatu angka yang disebut koefisien reliabilitas. Walaupun secara teoritis, besarnya koefisien reliabilitas berkisar antara $0,00-1,00$. 


\section{c. Uji Regresi Linear Sederhana}

Kegunaan regresi dalam penelitian ini salah satunya adalah untuk meramalkan atau memprediksi variabel terikat (Y) apabila variabel bebas (X) diketahui. Regresi linear sederhana dapat dianalisis karena didasari oleh hubungan fungsional atau hubungan sebab akibat (kausal) antara variabel bebas (X) terhadap variabel terikat (Y). Menurut Persamaan regresi linear sederhana dapat dirumuskan sebagai berikut (Alma,2009:97)

$$
\begin{aligned}
& Y=\alpha+b X \\
& \text { Keterangan : } \\
& \mathrm{Y}: \text { Variabel terikat atau response } \\
& \mathrm{X}: \text { Variabel bebas atau predictor } \\
& \alpha: \text { Nilai Konstanta } \\
& \mathrm{b}: \text { Koefisien Variabel X }
\end{aligned}
$$

Selain itu uji korelasi juga digunakan untuk mengetahui seberapa besar hubungan yang terjadi antara variabel $\mathrm{X}$ terhadap variabel $\mathrm{Y}$. Pada uji korelasi inisemakin $\mathrm{R}$ mendekati 1 maka hubungan yang terjadi semakin kuat, sedangkan semakin nilai $\mathrm{R}$ mendekati 0 maka hubungan yang terjadi semakin lemah. Adapun pedoman yang digunakan adalah sebagai berikut :

Tabel 3. Pedoman Interprestasi Nilai Korelasi

\begin{tabular}{cc}
\cline { 2 - 2 } Nilai $\mathbf{R}$ & Hasil \\
\hline $\mathbf{0 , 0 0}$ s/d 0,20 & Tidak ada korelasi \\
\hline $\mathbf{0 , 2 1}$ s/d 0,40 & Korelasi lemah \\
\hline $\mathbf{0 , 4 1}$ s/d 0,60 & Korelasi sedang \\
\hline $\mathbf{0 , 6 1}$ s/d 0,80 & Korelasi kuat \\
\hline $\mathbf{0 , 8 1}$ s/d 1,00 & Korelasi sempurna \\
\hline
\end{tabular}

d. Koefisien Determinasi

Koefisien determinasi $\left(\mathrm{R}^{2}\right)$ digunakan untuk mengukur seberapa besar variabelvariabel independen dapat menjelaskan variabel dependen. Koefisien ini menunjukan proporsi variabilitas total pada variabel dependen yang dijelaskan oleh model regresi. Nilai $R^{2}$ berada pada interval $0 \leq \mathrm{R}^{2} \leq 1$.

Secara logika dapat diketahui bahwa semakin baik estimasi model dalam menggambarkan data, maka makin dekat nilai $\mathrm{R}$ ke nilai 1 (satu). Nilai $\mathrm{R}^{2}$ dapat diperoleh dengan rumus : $\mathrm{R}^{2}=(\mathrm{r})^{2} \times 100 \%$

Keterangan :

$\mathrm{R}^{2}=$ Koefisien determinasi

$\mathrm{r}=$ Koefisien korelasi

1) Uji Hipotesis

Uji Parsial (Uji t)

Uji Parsial digunakan untuk menguji hipotesis dengan membandingkan antara $t_{\text {hitung }}$ dengan $t_{\text {tabel }}$ maka dapat diketahui ada atau tidaknya pengaruh Sistem Informasi Inventory (X) dengan Kinerja Karyawan (Y).

2) Uji Koefisien Regresi Simultan (Uji F)

Uji $F$ digunakan untuk mengetahui signifikasi pengaruh variable Sistem Informasi Inventory (X) secara (simultan) berpengaruh terhadap Kinerja Karyawan (Y)

\section{Tempat Penelitian}

Lokasi penelitian adalah di PT.YCH Indonesia yang beralamat di Jl. Kalimalang KM 2 Rt/Rw 02/07 Desa Sukadanau, Cibitung Bekasi-Jawa Barat 17520. 


\section{HASIL DAN PEMBAHASAN}

Tabel 4. Frekuensi rata-rata angka penafsiran pada variabel Sistem Informasi Inventory (X)

\begin{tabular}{|c|c|c|c|c|c|c|c|c|c|c|c|c|c|}
\hline & & \multicolumn{2}{|c|}{ Akurat } & \multicolumn{2}{|c|}{ Bentuk } & \multicolumn{2}{|c|}{ Frekuensi } & \multicolumn{2}{|c|}{ Bandwidth } & \multicolumn{2}{|c|}{ Asal } & \multicolumn{2}{|c|}{ Orientasi Waktu } \\
\hline & & $\mathrm{X} 1$ & $\mathrm{X} 2$ & $\mathrm{X} 3$ & $\mathrm{X} 4$ & $\mathrm{X} 5$ & $\mathrm{X} 6$ & $\mathrm{X} 7$ & $\mathrm{X} 8$ & $\mathrm{X} 9$ & $\mathrm{X} 10$ & $\mathrm{X} 11$ & $\mathrm{X} 12$ \\
\hline \multirow{3}{*}{$\mathbf{N}$} & Valid & 71 & 71 & 71 & 71 & 71 & 71 & 71 & 71 & 71 & 71 & 71 & 71 \\
\hline & Missing & 0 & 0 & 0 & 0 & 0 & 0 & 0 & 0 & 0 & 0 & 0 & 0 \\
\hline & Mean & 2.90 & 4.23 & 3.94 & 3.94 & 4.45 & 4.34 & 3.94 & 4.06 & 4.61 & 3.83 & 4.23 & 4.51 \\
\hline & & \multicolumn{2}{|c|}{ Tepat Waktu } & \multicolumn{2}{|c|}{ Relevan } & \multicolumn{2}{|c|}{ Lengkap } & \multicolumn{2}{|c|}{ Ekonomis } & \multicolumn{2}{|c|}{ Sederhana } & \multicolumn{2}{|c|}{ Dapat Dibuktikan } \\
\hline & & $\mathrm{X} 13$ & $\mathrm{X} 14$ & $\mathrm{X} 15$ & $\mathrm{X} 16$ & $\mathrm{X} 17$ & $\mathrm{X} 18$ & $\mathrm{X} 19$ & $\mathrm{X} 20$ & $\mathrm{X} 21$ & $\mathrm{X} 22$ & $\mathrm{X} 23$ & $\mathrm{X} 24$ \\
\hline \multirow{3}{*}{$\mathbf{N}$} & Valid & 71 & 71 & 71 & 71 & 71 & 71 & 71 & 71 & 71 & 71 & 71 & 71 \\
\hline & Missing & 0 & 0 & 0 & 0 & 0 & 0 & 0 & 0 & 0 & 0 & 0 & 0 \\
\hline & Mean & 4.51 & 4.17 & 4.62 & 4.39 & 4.45 & 4.34 & 4.17 & 4.56 & 3.89 & 4.34 & 4.11 & 4.39 \\
\hline
\end{tabular}

Dari tabel diatas dapat disimpulkan nilai frekuensi rata-rata masing-masing indikator :

$\begin{array}{lll}\text { Akurat } & (2.90+4.23 / 2) & =3.56 \text { (baik) } \\ \text { Bentuk } & (3.94+3.94 / 2) & =3.94 \text { (baik) } \\ \text { Frekuensi } & (4.45+4.34 / 2) & =4.39 \text { (Sangat baik) } \\ \text { Bandwidth } & (3.94+4.06 / 2) & =4.00 \text { (baik) } \\ \text { Asal } & (4.61+3.83 / 2) & =4.22 \text { (Sangat baik) } \\ \text { Orientasi Waktu } & (4.23+4.51 / 2) & =4.37 \text { (Sangat baik) } \\ \text { Tepat Waktu } & (4.51+4.17 / 2) & =4.34 \text { (Sangat baik) } \\ \text { Relevan } & (4.62+4.39 / 2) & =4.50 \text { (Sangat baik) } \\ \text { Lengkap } & (4.45+4.34 / 2) & =4,39 \text { (Sangat baik) } \\ \text { Ekonomis } & (4.17+4.56 / 2) & =4.36 \text { (Sangat baik) } \\ \text { Sederhana } & (3.89+4.34 / 2) & =4.11 \text { (baik) } \\ \text { Dapat dibuktikan } & (4.11+4.39 / 2) & =4.25 \text { (Sangat baik) }\end{array}$

Dari hasil perhitungan tersebut, maka nilai angka rata-rata penafsiran variabel X (Sistem Informasi Inventory) sebagai berikut:

$$
\begin{aligned}
& 3.56+3.94+4.39+4.00+4.22+4.37+4.34+4.50+4.39+4.36+4.11+ \\
& 4.25 \\
& = \\
& = \\
& \text { (12) }
\end{aligned}
$$

\begin{tabular}{|c|c|c|c|c|c|c|c|c|c|c|c|}
\hline & \multicolumn{3}{|c|}{ Kualitas } & \multicolumn{2}{|c|}{ Kuantitas } & \multicolumn{2}{|c|}{ Motivasi } & \multicolumn{3}{|c|}{ Inisiatif } \\
\hline & & Y1 & $\mathrm{Y} 2$ & $\mathrm{Y3}$ & Y4 & $\mathrm{Y} 5$ & Y6 & $\mathrm{Y7}$ & $\mathrm{Y} 8$ & $\mathrm{Y9}$ & Y10 \\
\hline \multirow{3}{*}{$\mathbf{N}$} & Valid & 71 & 71 & 71 & 71 & 71 & 71 & 71 & 71 & 71 & 71 \\
\hline & Missing & 0 & 0 & 0 & 0 & 0 & 0 & 0 & 0 & 0 & 0 \\
\hline & Mean & 4.28 & 4.11 & 4.34 & 4.51 & 4.17 & 4.17 & 4.11 & 4.34 & 4.34 & 4.34 \\
\hline
\end{tabular}

Tabel 5. Frekuensi rata-rata angka penafsiran pada variabel Kinerja Karyawan (Y)

Dari tabel diatas dapat disimpulkan nilai frekuensi rata-rata masing-masing indikator :

$$
\begin{aligned}
& \text { Kualitas } \quad(4.28+4.11+4.34 / 3)=4.24 \text { (Sangat baik) } \\
& \text { Kuantitas }(4.51+4.17 / 2)=4.34 \text { (Sangat baik) } \\
& \text { Motivasi }(4.17+4.11 / 2)=4.14 \text { (baik) } \\
& \text { Inisiatif }(4.34+4.34+4.34 / 3)=4.34 \text { (Sangat baik) }
\end{aligned}
$$

Dari hasil perhitungan tersebut, maka nilai angka rata-rata penafsiran variabel Y (Kinerja Karyawan) sebagai berikut:

$\begin{array}{ll}= & \frac{(4.24+4.34+4.14+4.34)}{4.26}\end{array}$




\section{Hasil Uji Analisis Data}

a. Persamaan Regresi Linier

Tabel 6. Persamaan Regresi Linier Var. X dan Y

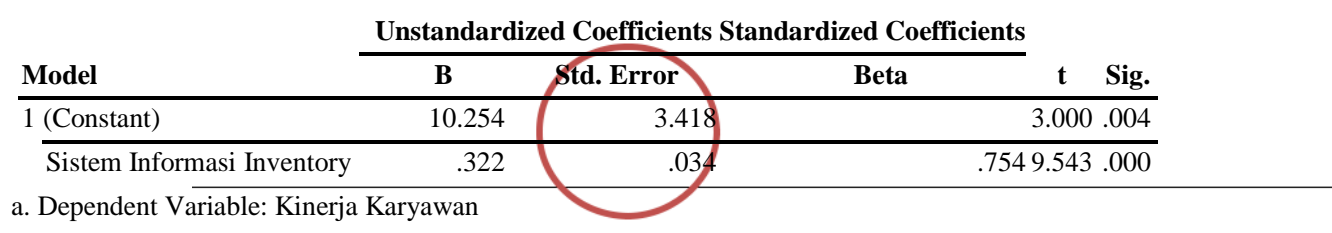

Dengan menggunakan SPSS 16.0 for windows dan mengacu pada Persamaan Regresi variabel $\mathrm{X}$ dan $\mathrm{Y}$ tersebut di atas terlihat bahwa nilai koefisien konstanta a sebesar 10,254 dan $b$ sebesar 0,322 . Dengan demikian sesuai dengan rumus yaitu $Y=a+b X$, dapat dibentuk dalam persamaan regresi $\mathrm{Y}=10,254+0,322 \mathrm{X}$.

b. Koefisien Korelasi

Untuk menghitung koefesien korelasi (r), hasil pengolahan data dengan menggunakan SPSS for windows ver. 16.0 yaitu :

Tabel 7. Koefisien Korelasi Pearson Product Moment

\begin{tabular}{|c|c|c|c|c|c|c|c|c|}
\hline \multirow[b]{2}{*}{ Model } & \multirow[b]{2}{*}{$\mathbf{R}$} & \multirow[b]{2}{*}{$\begin{array}{c}\text { R } \\
\text { Square }\end{array}$} & \multirow[b]{2}{*}{$\begin{array}{c}\text { Adjusted R } \\
\text { Square }\end{array}$} & \multirow[b]{2}{*}{$\begin{array}{c}\text { Std. Error of the } \\
\text { Estimate }\end{array}$} & \multicolumn{3}{|c|}{ Change Statistics } & \multirow[b]{2}{*}{$\begin{array}{l}\text { Sig. F } \\
\text { Change }\end{array}$} \\
\hline & & & & & $\begin{array}{c}\text { R Square } \\
\text { Change }\end{array}$ & $\begin{array}{c}\text { F } \\
\text { Change }\end{array}$ & df 1 df 2 & \\
\hline 1 & $.754^{\mathrm{a}}$ & & .563 & 2.950 & .569 & 91.062 & 169 & .000 \\
\hline
\end{tabular}

Maka pengaruh variabel Sistem Informasi Inventory terhadap Kinerja Karyawan pada PT.YCH Indonesia, menunjukan tingkat pengaruh yang kuat (baik) berdasarkan pedoman intepretasi. Hal ini ditunjukan oleh besarnya nilai koefisien korelasi sebesar 0,754.

c. Koefisien Determinasi

Tabel 8. Model Summary Koefisien Determinasi

\begin{tabular}{lllllll} 
Model $\quad \mathrm{R}$ & \multicolumn{4}{c}{ Change Statistics } \\
\hline 1 & $.754^{\mathrm{a}}$ & .569 & 2.950 & .56991 .062 & 169 & .000 \\
\hline
\end{tabular}

a. Predictors: (Constant), Sistem Informasi Inventory

Berdasarkan hasil olah data dengan menggunakan SPSS 16.0 for windows maka diperoleh nilai koefisien determinisi (R square) sebesar 0,569, yang berarti 56,9\%. Dengan demikian dari hasil analisis koefisien diterminasi/penentu tersebut, maka Sistem Informasi Inventory memiliki pengaruh sebesar $56.9 \%$ terhadap Kinerja Karyawan pada PT.YCH Indonesia, sementara sisanya $43.1 \%$ di pengaruhi faktor-faktor atau variabel-variabel lain yang tidak diteliti dalam penelitian ini.

d. Uji Hipotesis (Uji t)

Sebelum kita melakukan uji t, diajukan notasi sebagai berikut :

thitung $\quad=$ didapat dari perhitungan uji $\mathrm{t}$

tabel $\quad=$ didapat dari tabel dengan $\mathrm{df}=\mathrm{n}-2$

Jika $t_{\text {hitung }}>t_{\text {tabel }}$, maka notasi $\mathrm{H} 0$ ditolak dan $\mathrm{H} 1$ diterima

Jika $t_{\text {hitung }}<\mathrm{t}_{\text {tabel }}$, maka notasi $\mathrm{H} 0$ diterima dam $\mathrm{H} 1$ ditolak

Pengujian hipotesis untuk menentukan hipotesis yang telah ditetapkan pada bab sebelumnya. 
Hipotesis penelitan yang diajukan adalah sebagai berikut:

Jika nilai $t_{\text {hitung }}<\mathrm{t}_{\text {tabel }}$, maka $\mathrm{H} 0$ diterima dan $\mathrm{H} 1$ ditolak, artinya tidak terdapat pengaruh variabel sistem informasi inventory terhadap kinerja karyawan bagian operasional pada PT.YCH Indonesia.

Namun, jika nilai $t_{\text {hitung }}>t_{\text {tabel }}$, maka $\mathrm{H} 0$ tolak dan $\mathrm{H} 1$ diterima, artinya terdapat pengaruh variabel sistem informasi inventory terhadap kinerja karyawan bagian operasional pada PT.YCH Indonesia.

Untuk mengetahui besaran nilai $t_{\text {tabel }}$, terlebih dahulu ditentukan derajat kebebasan atau df yang merupakan banyaknya pengamatan bebas dari total pengamatan atau sampel (n) dengan rumus $(\mathrm{df}=\mathrm{n}-2, \mathrm{df}=71-2=69)$ pada presentase distribusi ( $\mathrm{t})$ sebesar 0,05 , setelah diketahui $\mathrm{df}=69$ dan $\mathrm{t}=0,05$ merujuk kepada tabel $\mathrm{t}$ maka dihasilkan nilai sebesar 1,667.

Tabel 9. Hasil Uji t

Unstandardized Coefficients Standardized Coefficients

\begin{tabular}{|c|c|c|c|c|}
\hline Model & $\mathrm{B}$ & Std. Error & Beta & Sig. \\
\hline 1 (Constant) & 10.254 & 3.418 & & 3.000 .004 \\
\hline Sistem Informasi Inventory & .322 & .034 & .754 & 9.543 .000 \\
\hline
\end{tabular}

Berdasarkan hasil olah data dengan menggunakan SPSS 16.0 for windows, terlihat hasil nilai

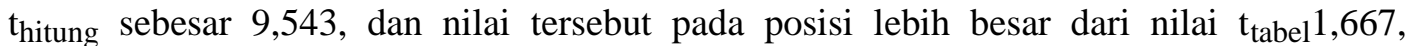
sehingga H0 ditolak dan H1 diterima. Dengan kata lain, hasil ini menunjukkan bahwa adanya pengaruh

variabel sistem informasi inventory terhadap kinerja karyawan bagian operasional pada PT.YCH Indonesia.

\section{Pembahasan}

Merujuk pada hasil penelitian yang dilakukan penulis, menunjukan adanya pengaruh yang positif dan siginfikan variabel $\mathrm{X}$ yaitu sistem informasi inventory terhadap variabel $\mathrm{Y}$ yakni kinerja karyawan bagian operasional pada PT.YCH Indonesia. Hal tersebut sesuai dengan hipotesis yang penulis sampaikan pada bab sebelumnya. Selanjutnya, mengacu pada hasil peneitian, berdasarkan hasil uji t terlihat bahwa nilai t-hitung $(9,543)$ lebih besar dari nilai t-tabel $(1,667)$ dan nilai signifikansi lebih kecil dari 0,05 . Hal tersebut menunjukan adanya pengaruh yang signifikan variabel sistem informasi inventory terhadap kinerja karyawan bagian operasional pada PT.YCH Indonesia. Adapun persentase besar pengaruh terlihat pada hasi uji determinasi yang menunjukan niali 0,569. Artinya pengaruh sistem informasi inventory terhadap kinerja karyawan bagian operasional pada PT.YCH Indonesia sebesar 56,9\%.

Dengan adanya hasil tersebut diatas, sejalan dengan teori bahwa kinerja karyawan dapat menjadi tolak ukur untuk mengetahui tingkat pencapaian hasil suatu instansi dihubungkan dengan visi yang diemban organisasi serta mengetahui dampak positif dan negatif dari suatu kebijakan operasional yang diambil . Artinya sistem informasi inventory pergudangan merupakan bentuk improvement yang dilakukan PT.YCH Indonesia dalam upaya meningkatkan kinerja karyawan yang tentunya akan berimbas juga terhadap peningkatan kualitas operasional perusahaan.

\section{E. KESIMPULAN}

Mengacu pada hasil penelitian dan pembahasan bab sebelumnya, maka penulis menyimpulkan bahwa :

1. Terdapat pengaruh yang signifikan antara sistem informasi inventory pergudangan terhadap kinerja karyawan bagian operasional PT.YCH Indonesia. Yang dibuktikan dengan hasil pengujian sebagai berikut 
a. Dengan hasil nilai koefisien konstanta a sebesar 10,254 dan konstanta b sebesar 0,322.

Sesuai dengan rumus yaitu $\mathrm{Y}=\mathrm{a}+\mathrm{bX}, \mathrm{Y}=10,254+0,322 \mathrm{X}$. Yang artinya:

Konstanta sebesar 10,254; artinya jika sitem informasi inventory (variabel $\mathrm{X}$ ) nilainya adalah 0, maka kinerja karyawan (variabel Y) nilainya positif yaitu sebesar 10,254.

Koefisien regresi variabel sistem informasi inventory $(\mathrm{X})$ sebesar 0,322 ; artinya jika sistem informasi inventory meningkat sebesar satu satuan, maka kinerja karyawan (Y) pada PT.YCH Indonesia meningkat sebesar 0,322 satuan

b. Hasil nilai thitung sebesar 9,543, dan nilai tersebut pada posisi lebih besar dari nilai $t_{\text {tabel }} 1,667$, sehingga H0 ditolak dan H1 diterima. Dengan kata lain, hasil ini menunjukkan bahwa adanya pengaruh variabel sistem informasi inventory terhadap kinerja karyawan bagian operasional pada PT.YCH Indonesia

2. Besarnya pengaruh sistem informasi inventory pergudangan terhadap kinerja karyawan bagian operasional PT.YCH Indonesia adalah sebagai berikut:

a. Pengaruh Sistem Informasi Inventory terhadap kinerja karyawan bagian operasional PT.YCH Indonesia, menunjukan tingkat pengaruh yang kuat (baik) berdasarkan pedoman intepretasi hal ini ditunjukan oleh besarnya nilai koefisien korelasi sebesar 0,745 .

b. Sistem Informasi Inventory memiliki pengaruh sebesar $56.9 \%$ terhadap Kinerja Karyawan pada PT.YCH Indonesia, sementara sisanya di pengaruhi faktor-faktor atau variabel-variabel lain.

\section{DAFTAR PUSTAKA}

Yudha, A. (2016). Pengaruh Sistem Pengendalian Persediaan Terhadap Kinerja Operasional Perusahaan Roti Nusa Indah Bakery Lhoknga, Aceh Besar. Etd Unsyiah.

Ariani, S. (2015). Pengaruh Sistem Pengendalian Intern Persediaan Terhadap Efektivitas Operasi Perusahaan (Studi Kasus Pada mini market Jaya iadah dan Pratama Mart Palembang) (Doctoral dissertation, Universitas Muhammadiyah Palembang).

Febianto, P. (2010). Pengaruh Sistem Informasi Inventory Gudang Terhadap Kinerja karyawan Bagian Gudang Di PT. Timur Raya Karya Mandiri Cabang Bandung (Doctoral dissertation, Universitas Komputer Indonesia).

Safitri, E. (2017). Pengaruh sistem pengendalian internal Persediaan bahan baku dan manajemen kontrol terhadap kinerja penjualan dengan sop sebagai variabel moderasi (studi kasus pada mcdonald's di tangerang selatan tahun 2017)

Ngei, N. M., \& Kihara, A. (2017). Influence of inventory management systems on performance of gas manufacturing firms in Nairobi city county, Kenya. International Journal of Business \& Law Research, 5(2), 21-39.

Sugiyono, (2013), Metode Penelitian,Pendekatan Kuantitatif, Kualitatif dan $R \& D$, Alfabeta, Bandung. 